\title{
POLA PENERBITAN JONI TAMKIN BIN BORHAN DALAM BIDANG EKONOMI ISLAM: KAJIAN BIOBIBLIOMETRIK (Pattern of Publication of Joni Tamkin Bin Borhan in Islamic Economic: Biobibliometric Studies)
}

\author{
Ahmad Faisal Abdul Hamid* \& Nurul Afiqah Hussin**
}

\begin{abstract}
Abstrak
Artikel ini membincangkan pencapaian Profesor Dr Joni Tamkin Borhan dalam penghasilan penerbitan ilmiah. Beliau adalah seorang Profesor dalam bidang ekonomi Islam di Jabatan Syariah Ekonomi, Akademi Pengajian Islam, Universiti Malaya. Pola penerbitan beliau dalam pelbagai bentuk seperti buku, jurnal dan lain-lain dibincangkan dalam artikel ini, begitu juga penggunaan bahasa serta bentuk kolaborasi beliau dengan tokoh penulis-penulis lain dalam penghasilan karya ilmiah. Sebelum itu, akan dijelaskan biodata ringkas mengenai diri beliau serta sumbangannya dalam bidang akademik dan kemasyarakatan. Data-data kajian diambil dari pengkalan data UM-Expert yang dikemaskinikan oleh beliau sendiri sebelum beliau meninggal dunia untuk pengetahuan umum mengenai aktiviti penulisannya dan penilaian pencapaian oleh pihak UM. Selain itu, temu bual dengan isteri beliau juga dilakukan untuk mendapat maklumat tambahan dan pengesahan beberapa fakta yang berkaitan. Kesimpulannya, beliau merupakan seorang profesor yang aktif dalam bidang penerbitan ilmiah dan juga banyak menyumbang kepada masyarakat umum sama ada secara langsung atau menjadi penasihat kepada instituis kewangan dalam negara. Beliau merupakan contoh yang baik kepada ahli akademik lain khususnya dalam bidang pengajian Islam dan ekonomi Islam.
\end{abstract}

Kata kunci: Joni Tamkin Borhan, penerbitan profesor, pola penerbitan, penerbitan ekonomi Islam

\begin{abstract}
This article discusses the achievements of Professor Dr Joni Tamkin Borhan in producing scientific publications. He was a Professor in Islamic economics at the Department of Shariah and Economics, Academy of Islamic Studies, University of Malaya. His publication patterns in various forms such as books, journal articles and others are discussed in this article, as well as the use of language and his kinds of collaboration with other writers' figures in the production of scientific works. Prior to that, this paper explains brief biodata about himself, his contributions in academic and also his involvement in community. The data was collected from his own UM-Expert database before he passed away. This database is used to share with others of his academic activities and also used as evaluation for his achievements by UM. In addition, interviews with his wife were also conducted for additional information and confirmation of some relevant facts. In conclusion, he was an active professor in the field of scientific publications and did contribute greatly either directly as an academician or through hi role as advisor to financial institutions in the country. This paper proofs that he is a good example of other academicians especially in the field of Islamic studies and Islamic economy.
\end{abstract}

Keywords: Joni Tamkin Borhan, Professor's publications, pattern of publications, publication of Islamic economic

\section{Pendahuluan}

Penghasilan karya ilmiah oleh ahli akademik ialah satu wadah penting ke arah menyampaikan ilmu pengetahuan baru kepada masyarakat disamping ia menjadi bahan rujukan buat generasi akan datang. Dari aspek pencapaian akademik pula, penghasilan karya tulis merupakan suatu penanda aras keupayaan akademik seseorang penyelidik dalam bidangnya. ${ }^{1}$ Selain itu, ilmu pengetahuan dan pengalaman yang didokumentasikan dan dibukukan dalam bentuk karya akan menjadi pemangkin

\footnotetext{
*Faisal @ Ahmad Faisal Abdul Hamid (Corresponding Author), Senior Lecturer, Department of Islamic History and Civilization, Academy of Islamic Studies, University of Malaya, Kuala Lumpur, Malaysia. E-mail: faisal@um.edu.my.

${ }^{* *}$ Nurul Afiqah Hussin, Graduate of Bachelor Degree of Usuluddin, Department of Islamic History and Civilization, Academy of Islamic Studies, University of Malaya, Kuala Lumpur, Malaysia. E-mail: nurulafiqahhussin@gmail.com.

${ }^{1}$ Faisal@ Ahmad Faisal Abdul Hamid dan Ainul Mardiah Ahmad Jihadi (2016), "Pola Penerbitan Mohd Yakub@ Zulkifli Mohd Yusoff Dalam Bidang Al-Quran: Kajian Biobibliometrik," Jurnal al-Tamaddun, Jil. 11, Bil. 2, h. 49.
} 
kepada aktiviti penulisan dalam penerbitan karya akademik seterusnya. ${ }^{2}$ Ia juga menjadi platform kepada semua maklumat sama ada dalam bidang ekonomi, kebudayaan, kesihatan, pemakanan, alam sekitar dan sosial.

Umumnya, profesor merupakan seorang pakar dalam bidang tertentu dan diiktiraf kepakarannya oleh agensi yang berwibawa dalam dan luar negara. Keberadaan serta bilangan professor di sesebuah universiti mengambarkan penguasaan ilmu pengetahuan di institusi tersebut. Statistik penerbitan di UM sejak tahun 2010 hingga 2014 memperlihatkan perkembangan yang baik dari tahun ke tahun. Perkembagna itu amat ketara pada tahun tahun 2010, sebanyak 7694 buah dalam pelbagai bentuk penerbitan ilmiah, bilangan itu bertambah kepada 8654 buah pada tahun 2011, walaupun pertambahan bilangan penerbitan ilmiah pada tahun 2012 hanya 149 buah sahaja berbanding tahun sebelumnya, namun momentum penerbitan itu masih rancak iaitu sebanyak 8803 buah. Manakala pada tahun 2013, pertambahan bilangan penerbitan adalah besar iaitu sebanyak 9537 buah penerbitan. Pada tahun 2014, para pensyarah UM telah menghasilkan penerbitan ilmiah sebanyak 10232 buah dalam pelbagai bentuk. ${ }^{3}$ Momentum penerbitan akademik bagi PTJ Akademi Pengajian Islam, Universiti Malaya selari dengan perkembangan penerbitan ilmiah di UM dalam tempoh 2010-2014.

Keupayaan Akademi Pengajian Islam menghasilkan penerbitan ilmiah yang besar pada setiap tahun berpaksikan kepada keupayaan ahli akademiknya yang terdiri dari 4 orang professor dam lebih dari 20 orang profesor madya dan disamping puluhan pensyarah dan pensyarah kanan serta calon di peringkat sarjana atau doktor falsafah. Keupayaan profesor di Akademi Pengajian Islam dalam menghasilkan karya ilmiah dalam bidang kepakaran masing-masing menjadi penanda aras kecemerlangan warga APIUM. Artikel ini akan membincangkan penerbitan salah seorang profesor dalam bidang ekonomi Islam di Jabatan Syariah dan Ekonomi, Akademi Pengajian Islam, Universiti Malaya (APIUM). Beliau bukan sahaja seorang profesor yang banyak menghasilkan penerbitan ilmiah, malah seorang ahli akademik yang aktif dalam pelbagai bidang dan banyak memberi sumbangan kepada masyarakat awam dan golongan ilmuan. Ketokohan beliau amat dikagumi di dalam dan juga luar negara.

Beberapa tajuk artikel yang pernah dihasilkan oleh Prof Dr Joni Tamkin dalam beberapa buah jurnal terbitan Akademi Pengajian Islam, UM memperlihatkan penguasaan dan wibawa akademik beliau dalam bidang Syariah Islam khususnya bidang ekonomi Islam. Berikut adalah contoh tajuk artikel yang pernah ditulis oleh beliau dari keseluruhan 56 artikel jurnal yang telah diterbitkan. ${ }^{4}$

\begin{tabular}{|c|c|c|}
\hline \multicolumn{3}{|c|}{ Jadual 1: Tajuk Penerbitan Prof Dr Joni Tamkin dalam Jurnal di APIUM } \\
\hline TAHUN & TAJUK ARTIKEL JURNAL & TERBITAN \\
\hline \multirow{3}{*}{1999} & A Survey of the Development of Islamic Economic Thought & Jurnal Usuluddin \\
\hline & $\begin{array}{l}\text { Bank Islam Malaysia Berhad: } \\
\text { Some Issues, Problems and Its Prospects in the Future }\end{array}$ & Jurnal Syariah \\
\hline & The Ethical Principles in Islamic Commercial Transactions & Jurnal Usuluddin \\
\hline \multirow{3}{*}{2000} & Pemikiran Perbankan Islam: Sejarah dan Perkembangan & Jurnal Usuluddin \\
\hline & The Tawhidic Paradigm in Islamic Banking & Jurnal Usuluddin \\
\hline & $\begin{array}{l}\text { Sumbangan Ibn Khaldun Dalam Pemikiran Ekonomi Islam dan } \\
\text { Relevensinya Dengan Permasalahan Ekonomi Semasa }\end{array}$ & Jurnal Afkar \\
\hline \multirow{4}{*}{2001} & $\begin{array}{l}\text { Sistem Perbankan Islam di Malaysia: } \\
\text { Sejarah Perkembangan, Prinsip dan Amalannya }\end{array}$ & Jurnal Usuluddin \\
\hline & $\begin{array}{l}\text { Pelaksanaan Prinsip al-Bay1 Bithaman Ajil Dalam Penggunaan } \\
\text { Kad Kredit Islam: Suatu Kajian di Arab-Malaysian Bank Berhad }\end{array}$ & Jurnal Syariah \\
\hline & $\begin{array}{l}\text { Falsafah Ekonomi dan Instrumen Muamalah Dalam Amalan } \\
\text { Perbankan Islam di Malaysia }\end{array}$ & Jurnal Usuluddin \\
\hline & $\begin{array}{l}\text { Peranan dan Cabaran Ekonomi Islam Dalam Era Globalisasi: } \\
\text { Suatu Analisis }\end{array}$ & Jurnal Afkar \\
\hline
\end{tabular}

\footnotetext{
2 Aswany Omar (2007), "Karya Ilmiah Wadah Ilmu Masyarakat,” Sinar Harian, 14 May 2007.

${ }^{3}$ Statistik penerbitan staff akademik UM di UM-Expert tahun 2010-2014.

${ }^{4}$ Rita Nur Suhaila (2015), "Pola Penghasilan Karya Ilmiah Profesor Dr. Joni Tamkin Bin Borhan,” Kertas Projek Di Jabatan Sejarah Dan Tamadun Islam, Akademi Pengajian Islam, Universiti Malaya, h. 67.
} 


\begin{tabular}{|c|c|c|}
\hline \multirow{4}{*}{2002} & Economic Functions of an Islamic State: An Analysis & Jurnal Usuluddin \\
\hline & Kewangan Menurut Perspektif Ekonomi Islam & Jurnal Syariah \\
\hline & Metodologi Ekonomi Islam: Suatu Analisis Perbandingan & Jurnal Usuluddin \\
\hline & $\begin{array}{l}\text { Beberapa Aaspek Pemikiran Syeikh Daud al-Fatani Dalam } \\
\text { Perbankan Islam: } \\
\text { Tumpuan Khusus Terhadap Kitabnya Furu` al-Masa il }\end{array}$ & Jurnal Afkar \\
\hline \multirow{4}{*}{2003} & $\begin{array}{l}\text { The Principle of al-Takaful (Collective Responsibility) in Islam } \\
\text { and Its Practice in the Operations of Syarikat Takaful Malaysia } \\
\text { Berhad }\end{array}$ & Jurnal Usuluddin \\
\hline & Quranic Principles of Islamic Banking & Jurnal Afkar \\
\hline & Al-Qur an; Miracles of the Miracles & Jurnal Al-Bayan \\
\hline & Istisna in Islamic Banking: Concept and Application & Jurnal Syariah \\
\hline \multirow{2}{*}{2004} & $\begin{array}{l}\text { The Agent-Manager s Conduct of Mudarabah Contract in } \\
\text { Islamic Commercial Law }\end{array}$ & Jurnal Syariah \\
\hline & An Analysis of The Prohibition of Riba in The Qur an & Jurnal Usuluddin \\
\hline 2005 & $\begin{array}{l}\text { The Role of Tabung Haji as a Deposit Mobilizer of Muslims in } \\
\text { Malaysia, } 1969 \text { 1990: A Historical Approach }\end{array}$ & Jurnal Tamadun \\
\hline 2006 & Peranan Wanita dalam Pengukuhan Akidah Umat Islam & Jurnal Usuluddin \\
\hline 2007 & Pemikiran Ekonomi Ibn Qayyim al-Jawziyyah & Jurnal Usuluddin \\
\hline 2008 & Pemikiran Pembangunan Ekonomi Berteraskan Islam & Jurnal Usuluddin \\
\hline 2012 & $\begin{array}{l}\text { Prospek Perbankan Islam Sebagai Medium Baru Dakwah di } \\
\text { Malaysia }\end{array}$ & Jurnal Usuluddin \\
\hline \multirow{2}{*}{2014} & $\begin{array}{l}\text { Faktor Penentu Pembayaran Zakat Oleh Entiti Perniagaan Di } \\
\text { Malaysia: Satu Tinjauan Teori. }\end{array}$ & Jurnal Syariah \\
\hline & $\begin{array}{l}\text { Krisis Kewangan Global: } \\
\text { Kestabilan Dan Karakteristik Unik Perbankan Islam }\end{array}$ & Jurnal Syariah \\
\hline
\end{tabular}

\section{Sorotan Kajian Lepas}

Kajian mengenai pola penerbitan ahli akademik adalah bertujuan mengukur produktiviti, trend dan bentuk penerbitan serta kolaborasi antara sesame ahli akademik. Antara mereka yang awal menulis dalam bentuk ini ialah Jerome H. Schiele pada tahun 1991..$^{5}$ Beliau telah membuat kajian terhadap produktiviti pola penerbitan tokoh akademik. Kajian beliau menggunakan kaedah analisis deskriptif. Beliau mengukur produktiviti berdasarkan enam pembolehubah dalam melihat pengaruhnya kepada jumlah penerbitan. Antara pembolehubah yang disenaraikan ialah (1) bekerja sebagai editor, (2) minat, (3) tempoh perkhidmatan, (4) jantina, (5) komitmen dalam penyelidikan dan (6) penjawatan. Setelah itu, Sangam L. Srcngcinz dan Kiran Savanur ${ }^{6}$ telah melakukan kajian terhadap penerbitan seorang profesor di Karnatak University, India, pada tahun 2006. Beliau melakukan kajian secara biografi, bibliometrik dan scientometrik. Pengkaji ini telah menggunakan kajian dengan menjelaskan terlebih dahulu latar belakang Dr N. Rudraiah yang merupakan penyelidik dalam bidang matematik di Universiti Bangalore. Dalam perbincangan penerbitan tersebut, beliau mengukur dari aspek pengaliran penerbitan dari tahun 1960 hingga 2005, aspek bilangan kepengkarangan, kolaborasi serta medium yang menjadi pilihan dalam menerbitkan bahan penerbitan.

Pada tahun 2006 juga, Susanta Koleya dan B. K. Sen ${ }^{7}$ membincangkan produktiviti secara individu menggunakan kaedah bio-bibliometrik terhadap Prof B. N. Koley yang merangkumi sepanjang

\footnotetext{
${ }_{5}^{5}$ Jerome H. Scheile (1991), "Publication Produktivity of African-American Social Work Faculty," Journal of Social Work Education, Jil. 27, Bil. 2, h. 125-134.

${ }^{6}$ S. L. Sangam dan Kiran Savanur (2006), "Dr. N. Rudraiah: A Biobibliometric Study,” SRELS Journal of Information Management, Jil. 43, Bil. 2, 185-199.

${ }^{7}$ Susanta Koley dan B. K. Sen (2006), “A Biobibliometric Study on Prof. B. N. Koley, an Eminent Physiologist,” Annals of Library and Information Studies, Jil. 53, 74 - 82.
} 
penglibatan beliau dalam aktiviti penyelidikan, penerbitan, pembentangan dan sumbangan-sumbangan lain. Dalam artikel Susanta Koleya dan B. K. Sen, mereka mengkaji jumlah penerbitan Koley dengan mengambil kira beberapa aspek dari segi kepengkarangan iaitu status dan corak kepengkarangan oleh Koley, jumlah penerbitan setiap 9 tahun, penyelidik kumpulan bersama dan tajuk-tajuk penulisan yang sering dijadikan penulisan oleh Koley sepanjang penerbitan beliau.

Manakala Antara kajian bibliomertik lain yang dapat dirujuk adalah kajian mengenai "Contribution of Dr. Anis Khurshid to Library Literature: A Blibliometric Study" yang telah ditulis oleh Khalid Mahmood dan Shafiq-ur-Rahman pada tahun 2010. Hasil daripada penulisan tersebut, beliau telah mendapat anugerah daripada Presiden Pakistan. Beliau telah menganalisis dari segi aspek tahun, jenis penerbitan, penulisan yang tidak diterbitkan dan tidak diterbitkan serta kolaborasi sepanjang penerbitan beliau. Hasil daripada kajian tersebut didapati beliau telah menghasilkan 21 buah buku, 94 artikel, 40 untuk penerbitan, 27 kertas laporan dan cadangan dalam tempoh 47 tahun. ${ }^{8}$

Mamoona Kousar dan Khalid Mahmood pada tahun $2010^{9}$ telah mengkaji salah seorang penulis prolifik dari data-data perpustakaan di Pakistan. Beliau mengkaji mengenai penghasilan karya Dr Syed Jalaluddin Haedar dengan menjelaskan biografi tokoh yang merangkumi latar belakang pengajian, bidang kerjaya, penyertaan persidangan penerbitan serta penyelidikan dan sumbangan-sumbangan lain. Dari sudut penerbitan pula, beliau membahagikan keseluruhan penerbitan mengikut item sepanjang tahun 1968 hingga 2008 iaitu buku, artikel, penerbitan, dan lain-lain. Seterusnya, beliau mengkaji pemilihan bahasa penulisan ilmiah, corak kepengkarangan, bilangan helaian, pemilihan jurnal terpilih dan penggunaan kata kunci sama ada hanya sekali atau berulang yang digunakan bagi mengetahui topiktopik yang sering menjadi pemilihan penulis. Kebanyakan kajian yang dibuat lebih tertumpu kepada tokoh sains tulen sama ada dalam bidang sains, matematik dan sebagainya.

Adapun di Malaysia pula, tidak ramai yang membuat kajian mengenai penerbitan tokoh dalam bidang kemanusiaan. Seorang penyelidik bernama Tiew Wai Sin telah membuat kajian bertajuk "Khoo Kay Kim, Professor of Malaysian History: A Biobibliometric Study. ${ }^{10}$ Dalam kajian ini, Tiew Wai Sin telah membentangkan analisis produktiviti penerbitan, corak penerbitan, saluran komunikasi, keutamaan jurnal dan pilihan bahasa Profesor Dato ' Khoo Kay Kim, Profesor Sejarah Malaysia di Universiti Malaya, Kuala Lumpur. Kesimpulan kajian beliau menunjukkan bahawa tokoh yang dikaji dapat dijadikan contoh kepada ahli sejarah Malaysia masa depan untuk mencontohi beliau dalam pelbagai pencapaian khususnya dalam bidang penghasilan karya sejarah. Pada tahun 2016, Ahmad Faisal Abdul Hamid dan Ainul Mardhiah Ahmad Jahidi menulis dalam Jurnal al-Tamaddun sebuah artikel bertajuk "Pola Penerbitan Mohd Ya'akub @ Zulkifli Mohd Yusoff dalam bidang al- Quran: Kajian Bibliometrik." 11

Oleh itu, dirasakan penulisan mengenai ketokohan professor dalam bidang pengajian Islam amat kurang diberi perhatian, maka kajian ini dijalankan bagi melihat pola penerbitan tokoh akademik khususnya dalam bidang pengajian ekonomi Islam. Pemilihan Profesor Dr joni Tamkin sebagai tokoh yang akan dikaji pola penerbitan beliau adalah sesuai sebagai satu kelangsungan daripada kajian sebelumnya dalam bidang kajian bio-bibliometrik, khususnya prof pengajian Islam.

Objektif kajian ini adalah untuk mengukur pencapaian penerbitan tokoh dan mengetahui bentuk atau pola penerbitan beliau sepanjang tempoh yang dikaji. Perbincangan ini juga bertujuan menjelaskan bentuk kolaborasi yang wujud antara tokoh dengan penulis atau penyelidikan lain dalam penghasilan karya beliau dan sejauhmana beliau berkolaborasi dalam penghasilan karya dan medium bahasa yang dipilih oleh tokoh untuk menerbitkan karya beliau.

\footnotetext{
${ }^{8}$ Khalid Mahmood dan Syafiq-ur-Rehman (t.t.), Contribution of Dr. Anis Kurshid to Library Literature: A Bibliometric Study (t.tp.t.t), h. 1.

${ }^{9}$ Mamoona Kousar dan Khalid Mahmood (2010), "Khalid Dr. Syed Jalaludin Haider: A Bio-bibliometric Study," Pakistan Journal of Information Management and Libraries, Jil. 11, h. 1-10.

${ }^{10}$ Tiew Wai Sin (1999), "Khoo Kay Kim, Professor of Malaysian History: A Biobibliometric Study," Malayisan Journal of Library and Information Science, Jil.4, Bil.2, h. 47-57.

${ }^{11}$ Faisal@ Ahmad Faisal Abdul Hamid dan Ainul Mardiah Ahmad Jihadi (2016) "Pola Penerbitan Mohd Yakub@, Zulkifli Mohd Yusoff Dalam Bidang Al-Quran: Kajian Biobibliometrik," Jurnal al-Tamaddun, Jil. 11 Bil. 2, h. 49-59.
} 


\section{Metodologi kajian}

Untuk mendapatkan data-data kajian yang berkaitan dengan penerbitan tokoh, pangkalan data UMExpert digunakan kerana data yang terdapat di situ dianggap asli dan sah. Ia merupakan pengkalan data individu yang diselenggarakan sendiri oleh tokoh secara berkala dan digunakan oleh pihak Universiti Malaya (UM) untuk mengukur pencapaian akademik semasa bagi setiap staf. Dalam pengkalan data UM-Expert, latar belakang peribadi tokoh, penerbitan ilmiah dalam pelbagai bentuk dimuat naik oleh beliau sendiri untuk memaparkan segala hasil kerja beliau setiap tahun.

Selain itu, semakan silang digunakan untuk mengesahkan penerbitan buku, artikel dalam jurnal, prosiding, tesis penyelidikan dan sebagainya dengan mendapatkan salinan hardcopy yang tersimpan di perpustakaan. Semakan untuk artikel yang diterbitkan secara online dilakukan mengunakan "MyUniNet Portal-Malaysian University Libraries \& National Library Network e-Resources" yang menyediakan beberapa kemudahan seperti "MyTO: Malaysian Theses Online" untuk pencarian tesis berkaitan dengan tajuk penyelidikan, "Malaysian Academic Library Union Catalog (MALcat) yang berfungsi mencari dan mengenalpasti maklumat di seluruh perpustakaan di Malaysia merangkumi buku, jurnal, e-book dan e-jurnal. Seterusnya "Malaysia Academic Library Institution Repisitory (MALRep)" berfungsi untuk pencarian dan mengenalpasti maklumat di seluruh perpustakaan IPT Repositori. Bagi penerbitan antarabangsa, maklumat diambil daripada pengkalan data ABI/INFORM Complete @ProQuest@, Cambridge Books Online, Cambridge Journals Online (2011-2015), Databib: Cataloging the World's Research Data Repositories, EBSCO Discovery Service, EBSCO e-Books, Emerald, ProQuest Education Journals, SpringerLink, Web of Science dan beberapa pengkalan data yang lain. Selain itu, curriculum vitae Prof Dr Joni Tamkin yang terdapat dalam simpanan isteri beliau juga dirujuk. ${ }^{12}$ Untuk memperkukuhkan sumber data dan keabsahannya, sesi temu bual juga diadakan bersama isteri beliau.

\section{Kelahiran dan Asal Usul}

Nama penuh beliau adalah Joni Tamkin Bin Borhan. Beliau dilahirkan pada 18 Jun 1966 Masihi bersamaan 28 Muharram 1389 Hijah di Permatang Guntung, Perak, Malaysia. Ibu beliau ialah Ngadiah binti Satimin dan bapa beliau adalah Wak Borhan dan berasal dari Bagan Datoh sebelum berhijrah ke Permatang Guntung untuk membuka penempatan baru bersama peneroka yang lain. Beliau hidup sangat bersederhana dan mendapatkan pendidikan yang sangat baik hasil dari didikan keluarga yang sederhana. Isteri beliau juga seorang pensyarah berjawatan Profesor Madya di Jabatan Akidah Dan Pemikiran Islam di Universiti Malaya, namanya Dr Che Zarina Binti Sa'ari. Hasil perkahwinan tersebut mereka telah dikurniakan tiga orang cahaya mata yang terdiri daripada dua lelaki dan seorang perempuan.

\section{Pendidikan}

Beliau menerima pendidikan awal di Sekolah Kebangsaan Teluk Birah di Teluk Intan, Perak (19731978) kemudian beliau melanjutkan pelajaran di peringkat menengah di Sekolah Menengah Agama AlUlum Al-Syar'iyyah, Bagan Datoh (1979-1981). Seterusnya beliau melanjutkan pelajaran menengah atas ke Kolej Islam Klang (KIK) ${ }^{13}$ atau sekarang dikenali sebagai Kolej Islam Sultan Alam Shah (KISAS) (1982-1983) dan tamat Sijil Pelajaran Malaysia (SPM) pada tahun 1983.

Seterusnya Joni Tamkin melanjutkan pelajaran ke peringkat pra universiti dalam bidang pengajian Islam di Universiti Malaya selama 2 tahun (1984-1986). Beliau mula mendapat pendidikan secara formal dalam bidang syariah apabila beliau melanjutkan dalam Ijazah Sarjana Muda Syariah di Universiti Malaya (1986-1989). Pada tahun 1994, beliau telah berjaya menamatkan pengajiannya peringkat Ijazah Sarjana di Universiti Malaya. Dalam tempoh 4 tahun beliau beliau telah menyambung Ijazah Kedoktoran di Universiti Edinburgh, United Kingdom dalam perkhususan Perbankkan Islam pada tahun 1997.

\footnotetext{
${ }^{12}$ Che Zarrina Sa'ari (2018), Pensyarah Jabatan Akidah dan Pemikiran Islam, temu bual pada 1 November 2018.

${ }^{13}$ Kolej Islam Sultan Alam Shah (KISAS) (2005), Kolej Islam Mutiara Ilmu, 1955-2005, Bangi: Malindo Printers, Selangor, h. $13-17$.
} 


\section{Kerjaya dan Sumbangan}

Beliau telah kembali pada tahun seterusnya dan berkhidmat di Universiti Malaya sebagai pensyarah pada 5 November 1997 dan dilantik jawatan Profesor Madya di Jabatan Syariah Ekonomi, Akademi Pengajian Islam, Universiti Malaya (APIUM) pada 8 November 1997. Sebelum itu, beliau telah memulakan kerjayanya sebagai tutor di Fakulti Syariah Akademi Pengajian Islam pada Julai 1990 sehingga Julai 1993 dan tutor di Jabatan Pengajian Islam Fakulti Sastera dan Sains Sosial Universiti Malaya pada Januari 1994 sehingga Oktober 1997. Beliau telah dilantik sebagai professor pada 31 Disember 2006. Beliau telah berkhidmat dengan Akademi Pengajian Islam, Universiti Malaya (APIUM) selama hampir 20 tahun dari tahun 1998 hingga beliau meninggal dunia pada tahun $2017 .{ }^{14}$

Sepanjang berkhidmat di Universiti Malaya, beliau banyak memberi sumbangan kepakarannya dalam pelbagai bidang terutamanya dalam bidang akademik samada di peringkat Universiti dan agensi luar. Kepakaran beliau dalam bidang perbankan Islam, ekonomi Islam dan transaksi islam menjadikan beliau banyak terlibat dengan institusi kewangan samada penasihat syariah atau penasihat jemputan. Beliau telah menjadi sarjana terawal berkhidmat sebagai Majlis Penasihat Syariah Bank Negara Malaysia pada tahun 2001 sehingga 2005.

Selain itu, beliau turut menjadi penasihat syariah agensi luar bagi perbankan Islam dan takaful antaranya penasihat Syariah RHB Islamic Bank (2005) ${ }^{15}$, Penasihat Syariah RHB Bank (2014), Penasihat Syariah MAA/Zurich Takaful (2014), Pengerusi Pakar Bidang Fiqh Dewan Bahasa dan Pustaka (2014), Majlis Ulama' International Shariah Research Academy for Islamic Finance (ISRA) (2015), Ahli Jawatankuasa Penghasilan Instrumen Pentaksiran (2004), dan Jawatankuasa Kawalan Mutu, Kementerian Pendidikan Malaysia. Sepanjang hayat beliau, banyak terlibat lebih kurang 89 aktiviti penilaian yang melibatkan penyelididikan, tesis dan buku dalam pelbagai peringkat dan institusi pendidikan. Sebanyak 81 kali beliau telah dijemput memberi syarahan dan pembentangan dalam konfrens dan seminar berkaitan ekonomi dan kewangan islam samada di dalam dan luar negara.

Beliau turut mendapat beberapa anugerah serta pengiktirafan daripda Universiti Malaya antaranya Anugerah Perkhidmatan Cemerlang dan Anugerah Sijil Perkhidmatan Cemerlang sebanyak lima kali iaitu pada 2002, 2004, 2006, 2010, dan 2010. Selain itu, beliau juga pernah memperolehi pingat gangsa dalam pameran poster daripada Minggu Terbuka APIUM 2014.

Beliau dilantik sebagai pensyarah pada 5 November 1997 dan jawatan profesor madya pada 8 November 2001 serta pada 31 Disember 2006 beliau juga dilantik sebagai profesor. Tugas dipikul dengan penuh semangat dan komitmen tinggi yang diberikan oleh beliau dalam dunia pendidikan tidak menghalang beliau untuk menabur baktinya kepada masyarakat, bangsa, agama dan negara. Beliau menyumbang ilmu dan kepakarannya dalam pelbagai bidang dan menganggotai banyak jawatankuasa di peringkat kebangsaan. Antaranya ialah:

1. Lembaga Penasihat Universiti Islam Malaysia (UIM), 2014-2015.

2. Timbalan Pengerusi di Pakar Bidang Fiqh Dewan Bahasa dan Pustaka (DBP), 20142015.

3. Panel Subjek Pendidikan Islam di Lembaga Peperiksaan Malaysia, 2005.

4. Penasihat Syariah di Bank Islam RHB, 2005 sehingga kini.

5. Ahli Jawatankuasa Kawalan Mutu di Kementerian Pendidikan Malaysia, 2004.

6. Ahli Jawatankuasa Pendapatan Instrumen Pentaksiran, 2004.

7. Penasihat Sukatan Program Diploma di Kolej Dar Al-Hikmah, 2003-2004.

8. Lembaga Pendidikan Ijazah Sarjana Muda Kewangan dan Perbankan di Universiti Utara Malaysia, 2003-2005.

9. Majlis Penasihat Kebangsaan Bagi Perbankan Syariah Dan Takaful di Bank Negara Malaysia, 2001-2005.

10. Pengerusi Jawatankuasa Kawalan Mutu bagi Program Penerbitan Buku Teks KBSM 2004 di Kementerian Pendidikan Malaysia, 2001.

\footnotetext{
14 Joni Tamkin bin Borhan (2015), Pangkalan Data UMExpert 2015, dalam simpanan Profesor Madya Dr Che Zarrina Sa'ari, Pensyarah Jabatan Akidah dan Pemikiran Islam.

${ }^{15}$ Bank Negara Malaysia (2017), List of Shariah Committee Members of the Islamic Financial Institutions as at $1^{\text {st }}$ May 2017.
} 
Seterusnya dari sudut penglibatan dalam pentadbiran Universiti Malaya, beliau pernah dilantik sebagai Ketua Jabatan Syariah dan Ekonomi Universiti Malaya pada 11 Julai 2003 sehingga 31 Disember 2003 dan kali kedua dilantik pada 25 Jun 2008 sehingga pada 31 Ogos 2009. Beliau dilantik sekali lagi sebagai Ketua Jabatan Syariah dan Ekonomi pada 1 Julai 2011 sehingga 30 Julai 2014. Selain itu beliau pernah memegang jawatan sebagai Pengerusi Jawatankuasa Peperiksaan PHD 2011-sekarang; Timbalan Pengarah Bahagian Siswazah 21-27 Febuari 2006, 1 April-Ogos 206 dan September 2006Ogos 2007; Penyelaras Bahagian Program Pengajian Islam 8 Jun-14 Jun 2006; Timbalan Pengerusi Jawatankuasa Tesis/Disertasi Lembaga Peperiksaan Akademi Pengajian Islam 1 April-31 Mei 2006 dan sebagainya.

Bukan itu sahaja, malah kehebatan seorang ahli akademik ialah apabila turut diakui oleh rakan sejawat di luar institusinya dan diminta untuk menjadi penilai sama ada kepada satu program atau penulisan tesis. Dr. Joni Tamkin tidak terkecuali dari dilantik sebagai penilai luar. Jawatan dan pengalaman akademik beliau ialah sebagai Ahli Panel Penilaian Laporan Kemajuan Calon Bright Sparks 2011; Ahli Jawatankuasa Penilai Anugerah Cemerlang Universiti Malaya 2012-Kategori Penerbitan; Pengerusi Jawatankuasa Penilaian Kurikulum Jabatan Syariah dan Ekonomi 2009; Ahli Jawatankuasa Penilaian Kurikulum Akademi Pengajian Islam 2005-2009; Ahli Senat Universiti Malaya 2012-2015; Editor Jurnal Syariah 2012-2014; Ketua Unit Penyelidikan Akademi Pengajian Islam 2011-2012; Pemangku Timbalan Pengarah Akademik Pengajian Islam 2012; Ahli Jawatankuasa MOU Keberkesanan Pelaksanaan antara Akademi dan Institusi Antarabangsa 2005-2007; Timbalan Pengarah Bahagian Siswazah Akademi Pengajian Islam 2006-2007; Timbalan Pengerusi Jawatankuasa Tesis/Disertasi Lembaga Peperiksaan Akademi Pengajian Islam 2006; Ahli Jawatankuasa Penerbitan Universiti Malaya 2004-2006 dan banyak lagi jawatan yang turut dipegang oleh beliau. ${ }^{16}$

\section{Perwatakan}

Profesor Dr Joni Tamkin adalah seorang yang sangat baik hati dan sentiasa membantu orang lain yang dalam keadaan susah. Beliau amatlah disenangi oleh orang sekelilingnya selain daripada ahli keluarga. Menurut isterinya ${ }^{17}$, beliau seorang yang sangat pemurah dan sentiasa menghulurkan bantuan kepada siapa sahaja khususnya daripada kalangan pelajar dan kakitangan Akademi Pengajian Islam Universiti Malaya yang memerlukan tidak kira jika ia berkaitan dengan kewangan, tenaga, fikiran dan lain-lain. Beliau juga sentiasa mengutamakan keluarga yang memerlukan bantuan darinya. sejak dari kecil lagi beliau adalah anak kesayangan keluarga dan tidak pernah lupa tanggungjawabnya sebagai anak terhadap ibubapa, adik-adik dan saudara mara lain.

\section{Kematian}

Profesor Dr Joni Tamkin bin Borhan meninggal dunia pada 19 Mei 2017 semasa berumur 51 tahun. Beliau telah disahkan meninggal dunia oleh Pusat Perubatan Universiti Malaya akibat daripada sakit jatung. Beliau meninggal semasa mengikuti Program pelajar ke Suruhanjaya Sekuriti Malaysia di Damansara. Jenazah beliau telah dibawa ke Surau Akademi Pengajian Islam Universiti Malaya untuk disembahyangkan sebelum diiring jenazah ke Tanah Perkuburan Islam Pantai Dalam.

\section{Penghasilan Penerbitan Ilmiah}

Jadual 1: Trend Penerbitan Ilmiah Tahun 1994-2015

\begin{tabular}{|c|c|c|c|c|c|c|c|c|}
\hline Tahun & Umur & Jawatan & Buku & $\begin{array}{c}\text { Bab } \\
\text { Buku }\end{array}$ & Artikel & Prosiding & Jumlah & $\begin{array}{c}\text { Peratus } \\
(\%)\end{array}$ \\
\hline 1994 & 28 & Tutor & 2 & 0 & 0 & 0 & 2 & 0.93 \\
\hline 1998 & 32 & \multirow{3}{*}{ Pensyarah } & 0 & 0 & 1 & 0 & 1 & 0.46 \\
\hline 1999 & 33 & & 0 & 0 & 3 & 0 & 3 & 1.4 \\
\hline 2000 & 34 & & 0 & 0 & 3 & 7 & 10 & 4.67 \\
\hline 2001 & 35 & \multirow[b]{2}{*}{ Prof } & 0 & 0 & 6 & 5 & 11 & 5.14 \\
\hline 2002 & 36 & & 0 & 1 & 5 & 2 & 8 & 3.73 \\
\hline
\end{tabular}

\footnotetext{
16 UMexpert-Prof. Dr. Joni Tamkin Bin Borhan (t.t.), laman sesawang Universiti Malaya, dicapai pada 20 Disember 2015 , http://umexpert.um.edu.my/joni.

${ }^{17}$ Che Zarrina Saa'ri (2018), pensyarah Jabatan Akidah dan Pemikiran Islam, dalam temu bual 1 November 2018.
} 


\begin{tabular}{|c|c|c|c|c|c|c|c|c|}
\hline 2003 & 37 & \multirow[t]{3}{*}{ Madya } & 0 & 2 & 5 & 4 & 11 & 5.14 \\
\hline 2004 & 38 & & 0 & 1 & 4 & 2 & 7 & 3.27 \\
\hline 2005 & 39 & & 1 & 4 & 1 & 18 & 24 & 11.2 \\
\hline 2006 & 40 & \multirow{10}{*}{ Profesor } & 1 & 2 & 1 & 18 & 22 & 10.2 \\
\hline 2007 & 41 & & 1 & 2 & 3 & 8 & 14 & 6.54 \\
\hline 2008 & 42 & & 1 & 4 & 2 & 14 & 21 & 9.81 \\
\hline 2009 & 43 & & 0 & 0 & 7 & 6 & 13 & 6.07 \\
\hline 2010 & 44 & & 0 & 0 & 2 & 8 & 10 & 4.67 \\
\hline 2011 & 45 & & 0 & 1 & 2 & 7 & 10 & 4.67 \\
\hline 2012 & 46 & & 0 & 5 & 6 & 8 & 19 & 8.87 \\
\hline 2013 & 47 & & 0 & 0 & 10 & 7 & 17 & 7.94 \\
\hline 2014 & 48 & & 0 & 2 & 4 & 4 & 10 & 4.67 \\
\hline 2015 & 49 & & 0 & 0 & 1 & 0 & 1 & 0.46 \\
\hline Jumlah & - & & 6 & 27 & 56 & 24 & 115 & \\
\hline$\%$ & & & 5.22 & 23.47 & 48.70 & 20.87 & 100 & \\
\hline
\end{tabular}

Sumber: Pangkalan Data UMExpert, 2015

\section{Rajah 1: Kekerapan Penerbitan Ilmiah Tahun 1994-2015}

50

40

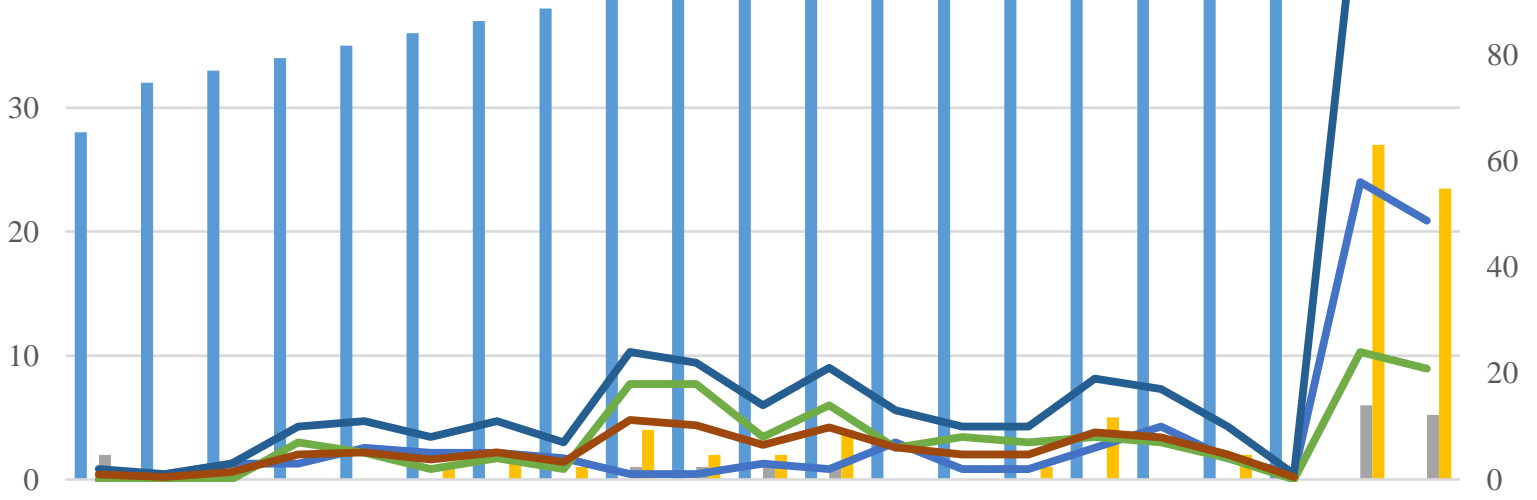

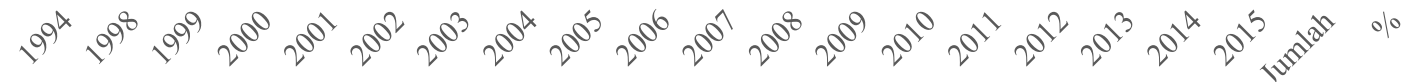

Umur Jawatan $\longrightarrow$ Buku Bab Buku $\longrightarrow$ Artikel $\rightleftharpoons$ Prosiding $\longrightarrow$

Sumber: Pangkalan Data UMExpert, 2015

Jadual 1 dan Rajah 1 di atas menunjukkan jumlah keseluruhan penerbitan Profesor Dr. Joni Tamkin bin Borhan sepanjang tahun 1994 hingga 2015. Beliau telah menghasilkan sebanyak 115 penerbitan dalam pelbagai bentuk antaranya bab buku, artikel dan prosiding samada dalam bentuk individu dan berkolaborasi bersama penyelidik lain dalam tempoh perkhidmatan beliau. Antara jumlah tertinggi penerbitan beliau adalah pada tahun 2005 sehingga 2012 iaitu sebanyak 14 hasil penerbitan. Hasil daripada 23 tahun beliau menceburi bidang akademi, beliau telah menghasilkan 6 buah buku, 27 bab dalam buku, 56 artikel dan 24 prosiding. 
Rajah 2: Kekerapan Penerbitan Buku Tahun 1994-2015

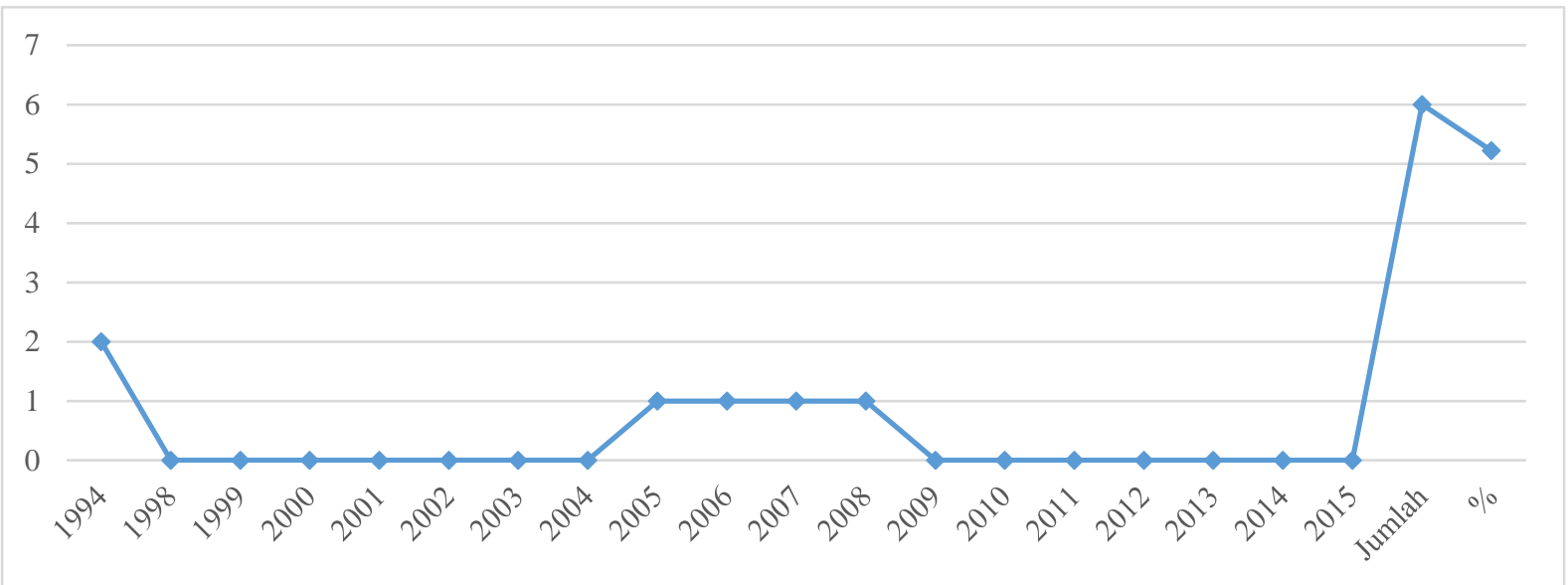

Sumber: Pangkalam Data UMExpert, 2015

Berdasarkan Rajah 2 menunjukkan kekerapan penulisan dan penerbitan berdasarkan karya ilmiah iaitu buku. Dalam rajah tersebut menunjukkan keseluruhan penghasilan karya Profesor Dr. Joni Tamkin bin Borhan dalam bentuk buku akademik adalah sebanyak 6 buah buku kesemuanya. Masing-masing sebuah buku pada tahun 2005 hingga 2008. Beliau telah mula menulis pada tahun 1994 pada ketika itu beliau berumur 28 tahun di mana beliau menulis 2 buah buku iaitu Ulum al-Quran al-Hadith bersama isterinya Dr. Che Zarina binti Sa'ari. Jika dilihat semula pada tahun 1995 sehingga 1997 beliau tidak menghasilkan sebarang karya penerbitan kerana menumpukan sepenuhnya pada pelajarannya di peringkat Sarjana Syariah dalam bidang ekonomi Islam dan juga menyiapkan tesis doktor falsafah.

\section{Bab dalam Buku}

Rajah 3: Kekerapan Penghasilan Bab dalam Buku Tahun 1994-2015

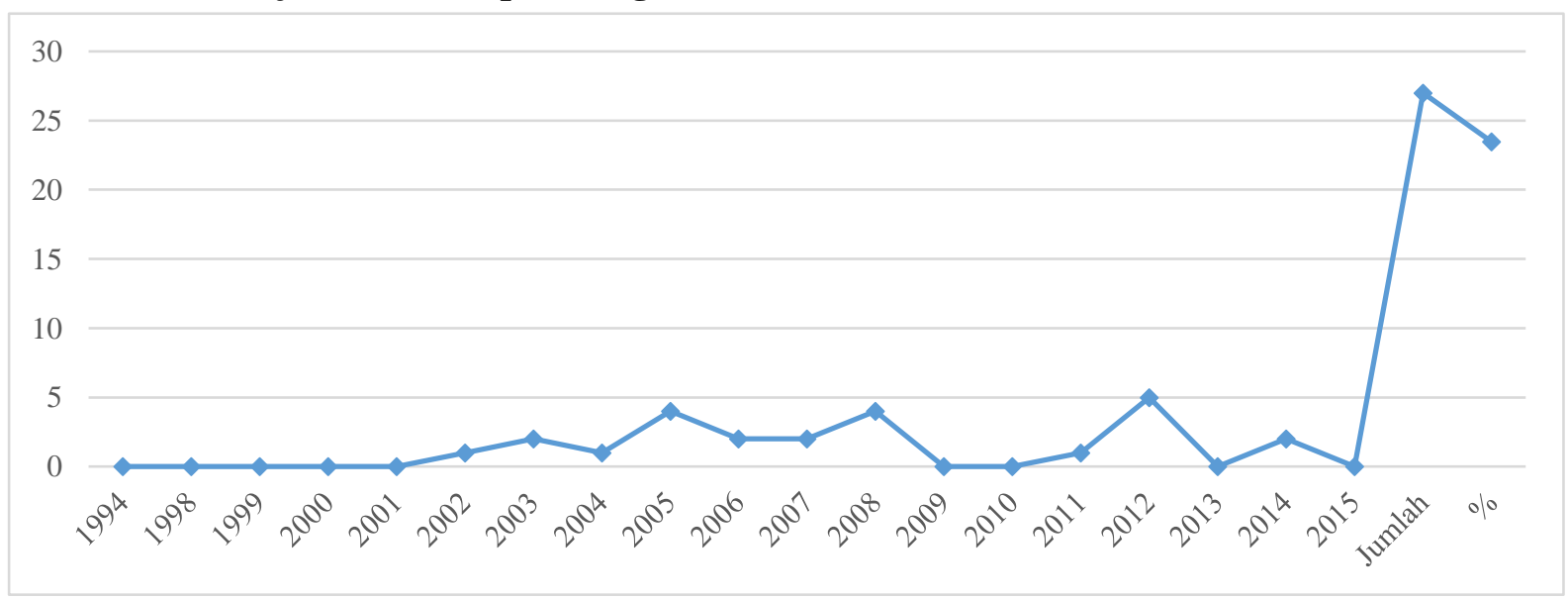

Sumber: Pangkalam Data UMExpert, 2015

Rajah 3 di atas menunjukkan bilangan penerbitan bab buku bagi tahun 1994 sehingga 2017. Jumlah keseluruhan penerbitan buku adalah sebanyak 12 bab buku. Penghasilan paling tinggi yang dihasilkan adalah pada tahun 2012 iaitu 5 bab buku. pada tahun 2005 dan 2008 telah dihasilkan 4 buah buku dan selebihnya pada kadar $2(2003,2006,2007$ dan 2014) dan penghasilan paling minimum yang dihasilkan adalah sebuah bab buku (2002, 2004 dan 2011). Antara tajuk buku yang boleh dilihat dalam beberapa buah buku seperti Islamic Economics, Banking and Finance: Concept and Critical Issues, Traformasi Penyelidikan dan Pengajian Islam, Sunnah Nabi: Realiti dan Cabaran Semasa dan Sistem Takaful di Malaysia: Isu-Isu Kontemporari. ${ }^{18}$

\footnotetext{
18 Joni Tamkin bin Borhan (2015), Pangkalan Data UMExpert 2015, dalam simpanan Profesor Madya Dr Che Zarrina Sa'ari, Pensyarah Jabatan Akidah dan Pemikiran Islam.
} 
Rajah 4: Kekerapan Penerbitan Artikel Tahun 1994-2015

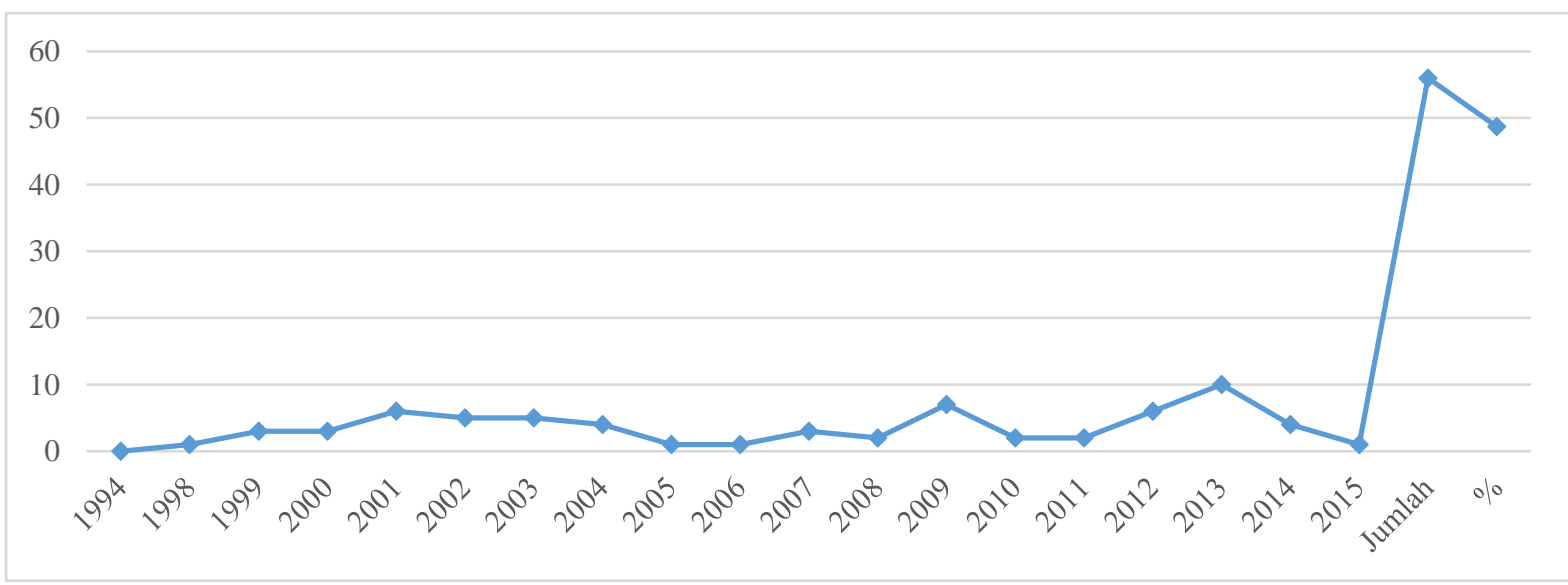

Sumber: Pangkalan Data UMExpert 2015

Rajah 4 di atas menunjukkan bilangan penerbitan artikel bermula pada tahun 1998 hingga 2015 adalah sebanyak 56 buah artikel. Jika dilihat bentuk penerbitan yang paling banyak dihasilkan oleh Profesor Dr Joni Tamkin bin Borhan adalah artikel iaitu sebanyak 56 buah. Penerbitan artikel yang paling tinggi adalah pada tahun 2013 iaitu sebanyak 10 buah artikel. Manakala, penerbitan artikel paling minimum pada bilangan satu adalah pada tahun 1998, 2005, 2006 dan 2008. Penulisan beliau telah diterbitkan di dalam Jurnal Syariah dan Jurnal Usuluddin di bawah Akademi Pengajian Islam Universiti Malaya (APIUM). Terdapat juga artikel beliau yang diterbitkan seperti di jurnal terindeks Scopus, Jurnal Jabatan Agama Islam Kelantan, Jurnal al- Tamadun, Jurnal Majlis Islam Sarawak dan Jurnal Afkar (JabatanAkidah dan Pemikiran Islam (APIUM).

\section{Prosiding}

Rajah 5: Kekerapan Penghasilan Prosiding Tahun 1994-2015

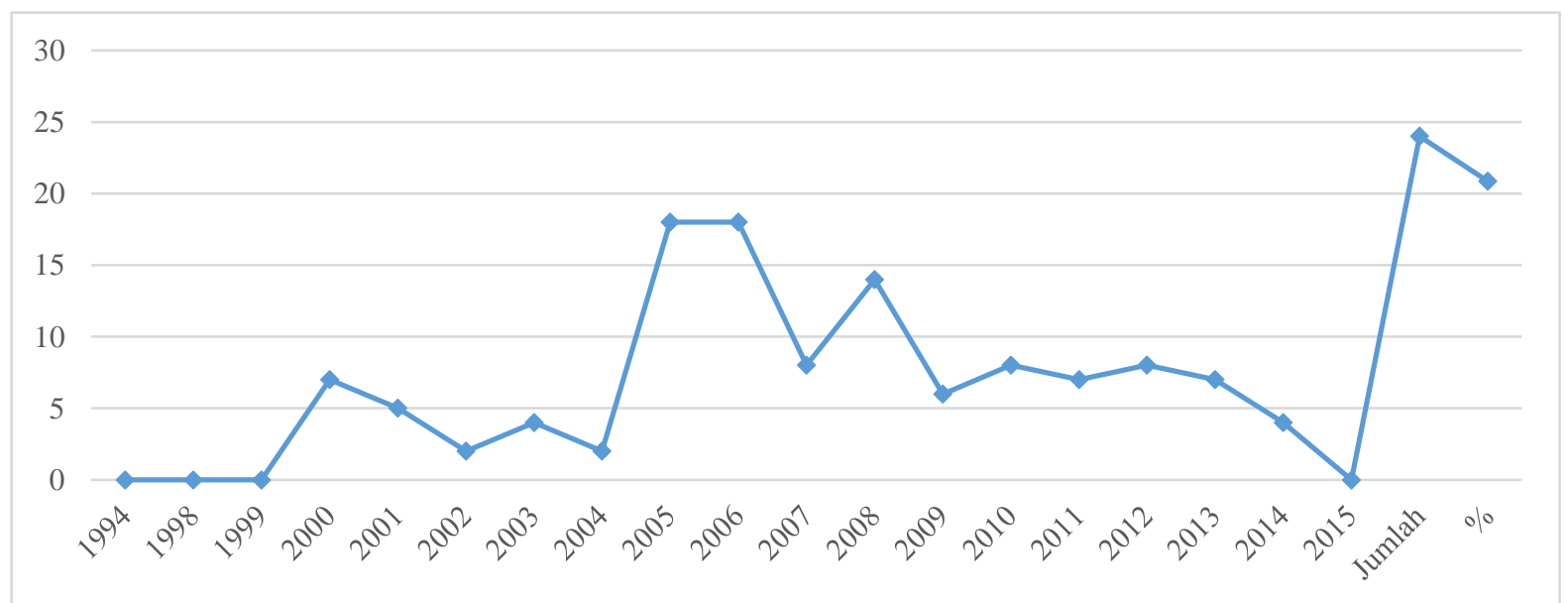

Sumber: Pangkalan Data UMExpert 2015

Rajah 5 di atas menunjukkan kekerapan penghasilan prosiding bermula tahun 1994 sehingga 2016. Jika dilihat daripada graf tersebut, prosiding adalah penerbitan yang paling banyak. Prosiding adalah bentuk terbitan yang dilakukan selepas dibentangkan dalam sesebuah persidangan dan harus melalui proses penilaian oleh seorang atau beberapa editor. Penghasilan prosiding paling tinggi iaitu 18 buah makalah pada tahun 2005 dan 2006. Diikuti pada tahun 2014 sebanyak 14 buah makalah, 8 buah makalah (2007, 2010 dan 20014), 7 buah makalah (2000, 2011 dan 2013), 5 buah makalah pada 2001, 4 buah makalah (2003 dan 2014), dan 2 buah makalah (2002 dan 2004). Graf tersebut menunjukkan bahawa data dilihat meningkat bermula pada tahun 2000 sehingga kemuncaknya tahun 2005 dan 2006 dan berperingkat menurun sehingga 2014. Ini kerana untuk penerbitan prosiding tidak memerlukan penelitian yang ketat seperti artikel. 
Jadual 2: Bilangan Kepengarangan Sepanjang Tahun 1994-2015

\begin{tabular}{|c|c|c|c|c|c|c|c|c|c|c|}
\hline Bilangan & $\mathbf{1 9 9 4}$ & $\mathbf{1 9 9 7}$ & $\mathbf{2 0 0 0}$ & $\mathbf{2 0 0 3}$ & $\mathbf{2 0 0 6}$ & $\mathbf{2 0 0 9}$ & $\mathbf{2 0 1 2}$ & $\mathbf{2 0 1 5}$ & Jumlah & Peratus (\%) \\
\hline Penulis & - & - & - & - & - & - & - & - & & \\
\hline & 1996 & 1999 & 2002 & 2005 & 2008 & 2011 & 2014 & & & \\
\hline 1 & 0 & 4 & 28 & 18 & 17 & 1 & 2 & 0 & 70 & 33 \\
\hline 2 & 2 & 0 & 1 & 23 & 28 & 19 & 19 & 0 & 92 & 43 \\
\hline $3 \geq$ & 0 & 0 & 0 & 2 & 12 & 13 & 25 & 0 & 52 & 24 \\
\hline & 2 & 4 & 29 & 43 & 57 & 33 & 69 & 0 & 214 & 100 \\
\hline
\end{tabular}

Sumber: Pangkalan Data UMExpert, 2015

Jadual 2 di atas menunjukkan statistik bilangan kepengarangan sepanjang tahun 1994 hingga 2016. Berdasarkan data di atas, bilangan tertinggi merupakan hasil daripada dua penulis iaitu sebanyak 92 buah penerbitan (43\%). Diikuti dengan 70 buah penerbitan (33\%) dihasilkan secara perseorangan. Ini menunjukkan bahawa beliau lebih gemar menghasilkan bahan penulisan secara dua penulis berbanding dengan bilangan penulis yang lain.

\section{Bahasa dalam Penerbitan}

Jadual 3: Bahasa dalam Penerbitan Tahun 1994-2015

\begin{tabular}{|l|c|c|c|c|c|c|}
\hline Bahasa & Buku & Bab dalam Buku & Artikel & Prosiding & Jumlah & Peratus (\%) \\
\hline Melayu & 5 & 19 & 32 & 62 & 118 & 55.1 \\
\hline Inggeris & 1 & 5 & 34 & 56 & 96 & 44.8 \\
\hline Arab & - & - & - & - & - & - \\
\hline Jumlah & 6 & 24 & 66 & 118 & 214 & 100 \\
\hline
\end{tabular}

Sumber: Pangkalan Data UMExpert, 2015

Jadual 3 di atas menunjukkan lebih daripada separuh, iaitu 55.1\% penerbitan ilmiah yang dihasilkan menggunakan Bahasa Melayu secara keseluruhannya sepanjang tahun 1994 hingga 2016, berbanding penggunaa Bahasa Inggeris sebanyak 44.8\% . Beliau tidak menggunakan Bahasa Arab dalam manamana penerbitan. Kekerapan Bahasa Melayu digunakan adalah sebanyak 118 kali dan Bahasa Inggeris sebanyak 96 kali. Jika dilihat beliau gemar menggunakan Bahasa Inggeris, berkemungkinan kerana faktor beliau pernah menuntut ilmu di peringkat PhD di Universiti Edinburgh, United Kingdom. Secara keseluruhannya beliau kerap menggunakan Bahasa Melayu dan Bahasa Inggeris.

\section{Perbincangan}

Daripada data-data yang dipaparkan di atas, dapatlah dikatakan bahawa Prof Dr Joni Tamkin adalah seorang ahli akademik mempunyai tahap pengalaman dan penguasan yang mendalam dalam bidang ekonomi Islam. Beliau adalah seorang yang aktif dalam penulisan dalam pelbagai bentuk penulisan bermula dari tahun 1994 sehingga 2015. Beliau telah mula berjinak dengan penulisan ilmiah sejak dari awal kerjaya akademik lagi semasa menjadi tutor, pada tahun 1998 beliau menjawat jawatan pensyarah di Akademi Pengajian Islam Universiti Malaya (APIUM). Oleh kerana beliau banyak menghasilkan penulisan ilmiah sejak awal kerjaya dan bakat itu telah meyakinkan pihak pentadbiran Universiti Malaya untuk menganugerahkan jawatan Prof. Madya pada usia beliau baru 35tahun.

Dengan keyakinan dan kepercayaan oleh pihak UM terhadap beliau, Prof Dr Joni Tamkin terus giat menulis dan menyumbang ke arah penghasilan karya ilmiah dalam pelbagai bentuk penulisan. Beliau adalah seorag penulis yang konsisten, tidak banyak penulisan beliau dalam setahun. Namun beliau tidak pernah berhenti munulis walaupun beliau sibuk dengan tugas-tugas pentadbiran dan kemasyarakatan.

Kesarjanaan beliau amat terserlah semasa menjawat jawatan tutor lagi, iaitu pada tahun 1994, beliau telah menghasilkan dua buah buku bersama dengan isterinya Dr Che Zarina. Walaupun kedua buku tersebut tidak berkaitan dengan ekonomi Islam, namun sudah memadai untuk membuktikan keupayaan 
serta penguasan beliau dalam ilmu pengajian Islam. Setelah itu, bakat yang dicungkil seawal umur 28 tahun itu dikembangkan sehingga beliau bejaya menulis sebanyak 115 tulisan dalam pelbagai bentuk penerbitan. Pada tahun 2005, 2006, 2007 dan 2008 adalah tahun-tahun aktif bagi Dr Joni dalam menghasilkan penulisan buku.

Dari aspek kepengarangan pula, beliau dilihat gemar menulis secara berkolaborasi berbanding berseorangan. Daripada keseluruhan 214 penerbitan beliau, hanya 70 buah penerbitan yang ditulis secara individu iaitu sebanyak 33\%. Mungkin disebabkan penulisan secara berkolaborasi adalah lebih berkesan dan banyak input dari aspek lain yang boleh dikongsikan. Beliau sering menulis bersama dengan isterinya dalam bidang psikoterapi Islam atau spiritual Islam yang dikaitkan dengan ekonomi Islam. Sebagai contoh, tulisan bertajuk peranan wanita dalam pengukuhan akidah umat Islam. ${ }^{19}$ Dalam artikel tersebut, beliau menuyumbang idea mengenai peranan wanita dalam aspek kemasyarakatan bersama dengan isterinya yang mempunyai kepakaran dalam bidang akidah. Beliau juga pernah menulis serta berkolaborasi dengan rakan-rakan penyelidik lain dalam mengahsilkan karya akademik. ${ }^{20}$

Penghasilan dari aspek bahasa pula terdapat tiga Bahasa utama iaitu Bahasa Melayu, Inggeris dan Arab. Tetapi beliau lebih gemar menulis dalam Bahasa Melayu dan Bahasa Inggeris. Mungkin kerana latarbelakang pengajian beliau di Malaysia dan juga di UK menjadikan beliau lebih mahir dalam kedua bahasa tersebut berbanding bahasa Arab.

\section{Kesimpulan}

Kesimpulanya, penghasilan karya penulisan dan penerbitan bagi ahli akademik adalah merupakan satu kayu ukur dalam dunia akademik. Kementerian Pengajian Tinggi juga telah menetapkan bagi memenuhi Key Performance Index (KPI) kepada pihak universiti. Ini sekaligus membantu meningkatkan serta menggalakkan masyarakat membuat penyelidikan serta dapat menambahkan ilmu pengetahuan dari pelbagai aspek. Profesor Dr Joni Tamkin bin Borhan adalah salah seorang tokoh yang harus dijadikan contoh dan semangat kepada masyarakat luar khasnya kepada pelajar pensyarah, pelajar dan juga penyelidik di Universiti Malaya sebagai satu penanda aras pencapaian mereka.

Dari apa yang telah dibincnagkan di atas, nyata memperlihatkan bahawa seorang pensyarah universiti tidak seharusnya lemah atau tidak menulis karya akademik walaupun mereka sibuk dengan tugsana pentadbiran atau khidmat sosial. Itu kerana penulisan ilmiah adalah suatu yang sebati dengan ge;aran ilmuan dan mereka seharusnya menulis dan berbangga kerana dapat menghasilkan karya tulis. Jika ahli akademik tidak lagi menulis maka pastinya orang yang tidak layak dan berpengetahuan yang mendalam dalam sesuatu bidang akan menulis dan mengisi kelompongan ilmu dalam kalangan masyarakat, di kala itu pastinya kesilapan dan kesalahan fakta atau teori akan berleluasa berbanding ilmu yang benar.

Hasil daripada perbincangan bibliometrik ini secara tidak langsung dapat menjelaskan sumbangan Profesor Dr Joni Tamkin bin Borhan dalam bidang ekonomi Islam khususnya. Diharapkan dengan kajian ini dapat meneruskan legasi kecemerlangan akademik para ilmuan Islam di Universiti Malaya dan IPT yang lain.

\section{Penghargaan}

Penulis ingin merakamkan penghargaan kepada Profesor Madya Dr Che Zarrina Saa'ri iaitu balu kepada Profesor Dr Joni Tamkin yang sudi ditemu ramah untuk mendapat maklumat tambahan serta pengesahan data. Semoga roh Profesor Dr Joni Tamkin Borhan sentiasa dicucuri rahmat serta ditempatkan dikalangan orang beriman. Amin.

\footnotetext{
${ }^{19}$ Che Zarrina Sa'ari dan Joni Tamkin (2006), “Peranan Wanita Dalam Pengukuhan Akidah Umat Islam," Jurnal Usuluddin, Jil. 23-24, h. 3550.

${ }^{20}$ Che Zarrina Sa'ari (2018), Pensyarah Jabatan Akidah dan Pemikiran Islam, temu bual pada 1 November 2018
} 


\section{Rujukan}

Aswany Omar (2017), “Karya Ilmiah Wadah Ilmu Masyarakat,” Sinar Harian, 14 May 2007.

Bank Negara Malaysia (2017), List of Shariah Committee Members of the Islamic Financial Institutions as at $1^{\text {st }}$ May 2017.

Che Zarrina Sa'ari (2018), Pensyarah Jabatan Akidah dan Pemikiran Islam, temu bual pada 1 November 2018

Che Zarrina Sa'ari dan Joni Tamkin (2006), "Peranan Wanita Dalam Pengukuhan Akidah Umat Islam," Jurnal Usuluddin, Jil. 23-24, 35-50.

Faisal @ Ahmad Faisal Abdul Hamid dan Ainul Mardiah Ahmad Jihadi (2016), "Pola Penerbitan Mohd Yakub @ Zulkifli Mohd Yusoff Dalam Bidang Al-Quran: Kajian Biobibliometrik," Jurnal alTamaddun, Jil. 11, Bil. 2, 49-59.

Joni Tamkin Bin Borhan (2015), laman sesawang Universiti Malaya, dicapai pada 20 Disember 2015, http://umexpert.um.edu.my/joni.

Joni Tamkin bin Borhan (2015), Pangkalan Data UMExpert 2015, dalam simpanan Profesor Dr Che Zarrina Sa'ari Pensyarah Jabatan Akidah dan Pemikiran Islam.

Khalid Mahmood dan Syafiq-ur-Rehman (t.t.), Contribution of Dr. Anis Kurshid to Library Literature: A Bibliometric Study, (t.tp.).

Kolej Islam Sultan Alam Shah (KISAS) (2005), Kolej Islam Mutiara Ilmu, 1955-2005, Bangi: Malindo Printers.

Koley, Susanta dan Sen, B. K. (2006), “A Biobibliometric Study on Prof. B. N. Koley, an Eminent Physiologist," Annals of Library and Information Studies, Jil. 53, 74 - 82.

Mamoona Kousar dan Khalid Mahmood (2010), "Khalid Dr. Syed Jalaludin Haider: A Bio-bibliometric Study", Pakistan Journal of Information Management and Libraries, Jil. 11, 1-10.

Rita Nur Suhaila (2015), "Pola Penghasilan Karya Ilmiah Profesor Dr. Joni Tamkin Bin Borhan," Kertas Projek Di Jabatan Sejarah Dan Tamadun Islam, Akademi Pengajian Islam, Universiti Malaya.

Sangam, S. L. and Savanur, Kiran P. (2006), "Dr. N. Rudraiah: A Biobibliometric Study," SRELS Journal of Information Management, Jil. 43, Bil. 2, 185-199.

Scheile, Jerome H. (1991), "Publication Produktivity of African-American Social Work Faculty," Journal of Social Work Education, Jil. 27, Bil. 2, 125-134.

Statistik penerbitan staff akademik UM di UM-Expert tahun 2010-2014.

Tiew Wai Sin (1999), "Khoo Kay Kim, Professor of Malaysian History: A Biobibliometric Study," Malayisan Journal of Library and Information Science, Jil.4, Bil.2, 47-57. 
Journal of Al-Tamaddun, Vol. 15 (2), 2020, 163-175 